\title{
A Record of Fish Anomaly from the Sea of Marmara, Turkey: European Hake (Merluccius merluccius Linnaeus, 1758) Missing the Right Eye
}

\author{
Uğur Uzer ${ }^{1}$ (D), F. Saadet Karakulak ${ }^{1}$
}

Cite this article as: Uzer, U., \& Karakulak, F.S. (2022). A record of fish anomaly from the sea of Marmara, Turkey: European hake (Merluccius merluccius Linnaeus, 1758) missing the right eye. Aquatic Sciences and Engineering, 37(2), 64-68.

ORCID IDs of the author:

U.U. 0000-0002-7038-6469;

F.S.K. 0000-0002-6053-5256

'Department of Fisheries Technology and Management, Faculty of Aquatic Sciences, Istanbul University, Istanbul, Turkey

Submitted:

06.10.2021

Revision Requested:

07.11.2021

Last Revision Received:

13.12.2021

Accepted:

14.12.2021

Online Published:

21.01.2022

Correspondence:

Uğur Uzer

E-mail:

uguruzer@istanbul.edu.tr

\section{ABSTRACT}

Abnormalities of shape, color or body deformities such as lack of swim bladders or any parts of the body are an unexplained issue for many fish species. There is a gap of knowledge regarding their causes. Generally, it is an important problem in the rearing technique in aquaculture management due to the high economic consequences. The morphological abnormalities occur in marine fishes as well. Missing dorsal spines or rays, scale disorientation, jaw deformities, eye deformations and the lack of some parts of the body are within the context of abnormality. In the present study, the body abnormality observed in a specimen of European hake (Merluccius merluccius Linnaeus, 1758) missing its right eye which was caught by a fisherman in the Marmara Sea on 13 October 2020, and its causes are reported and discussed. Further studies are needed to correlate the wild fish anomalies caused by pollution.

Keywords: Anomaly, European hake, Abnormality, Izmit bay, Sea of Marmara

\section{INTRODUCTION}

Morphological deformities are substitute indicators of the results of habitat degradation on fish populations (Sindermann, 1979). An anomaly in fishes could be one of the results of marine pollution, and heavy metals may be considered as the main causative agent of many fish anomalies (Jawad and Ibrahim, 2021). Those abnormalities are irreversible deviations, whether natural or caused, from the ordinary morphology of wild fish. The predominant morphological abnormalities in fish can be grouped into five primary classes including: skeleton, body form, scales, pigmentation and swim bladder (Divanach et al., 1996). The abnormalities are not unusual issues in aquaculture, where the purpose is to supply a great number of fish in keeping with purchaser demand (Daoulas et al., 1991; Boglione et al., 1993). Above all, anomalies within the elaborate opercular are also regular in different fish species (Valentine, 1975; Hilomen-Garcia, 1997). Morphological and structural abnormalities can arise and have a negative effect on the biological features which include respiration by physical damage to the gills and causes fungi infection, parasites and microorganisms (Bruno \& Poppe, 1996; Galeotti et al., 2000).

This paper describes the physical body abnormality observed in the European hake (Merluccius merluccius Linnaeus, 1758) of an individual without its right eye obtained from the Bay of Izmit, in the Marmara Sea on 13 October 2020.

\section{MATERIAL AND METHODS}

The specimen of European hake (M. merluccius) obtained from Izmit Bay (in the eastern part of the Marmara Sea), was caught with the commercial bottom gill-nets used by the fishermen in the region on 13 October 2020 at the depth of 70 meters (Figure 1). As soon as the fish was captured and the decision of the abnormality of the fish was determined, a fisherman put the specimen into a deep freezer and 
brought it to the Istanbul University Faculty of Aquatic Sciences laboratory to be examined and the body measurements were recorded to the nearest millimeters with a caliper.

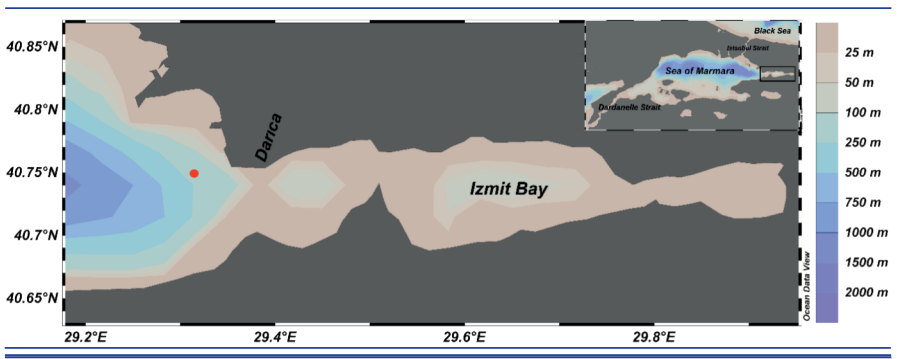

Figure 1. Geographical location of the capture of European hake in Izmit Bay (Sea of Marmara).

The Marmara Sea is $240 \mathrm{~km}$ in length and $70 \mathrm{~km}$ in width and has an area of $11,500 \mathrm{~km}^{2}$. The Marmara Sea is under the effect of waters of the Mediterranean and Black Seas. The waters coming from the Black Sea form the upper layer of the Marmara Sea, and the waters from the Mediterranean Sea represent the lower layer. The waters originating from the Black Sea and Mediterranean Sea are separated inside the Marmara Sea via an interface layer at a depth of about 25 m. (Beşiktepe et al.,1994). It has a rich dynamic structure concerning the pelagic and demersal fish species population. Being between the two different seas, the Black Sea and Mediterranean Sea, the Marmara Sea is a completely unique environment for the fish species harboring, feeding, and breeding habitat (Kocataş et al., 1993).

Izmit Bay is located along the northeastern part of the Marmara Sea. About two million people stay nearby Izmit Bay, especially in three massive metropolitan areas consisting of Izmit, Yalova, and Tuzla.

\section{RESULTS AND DISCUSSION}

Abnormality was recorded in one specimen of European hake in Izmit Bay. The European hake specimen was obtained from Izmit bay (Sea of Marmara), captured by fishermen during a gill-net fishery. The specimen had a normal body shape, but the right eye was missing with no injury (Figure 2). The total body length was $38.6 \mathrm{~cm}$ and the total weight was $492.59 \mathrm{~g}$ (Table 1).
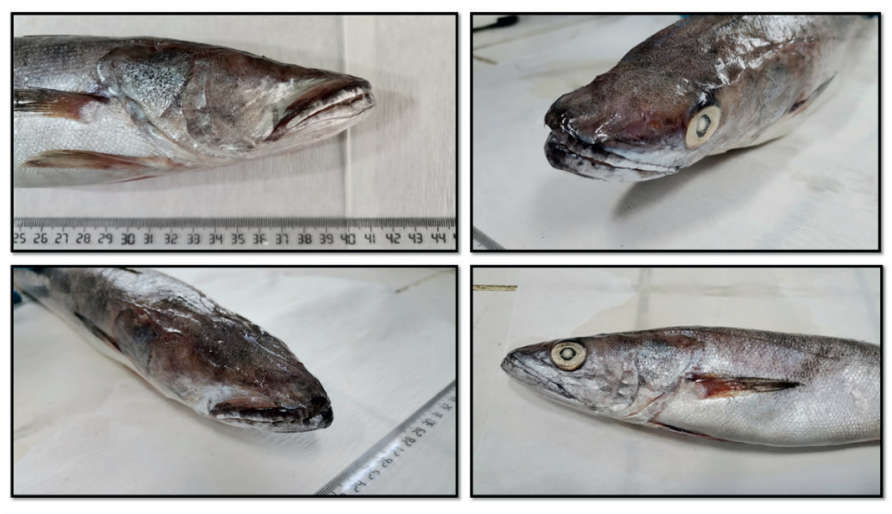

Figure 2. The abnormal specimen of European hake (Merluccius merluccius Linnaeus, 1758).
Table 1. Morphometric characteristics of the $M$. merluccius specimen from the Sea of Marmara (Izmit Bay) (all measurements are in $\mathrm{mm}$ )

\begin{tabular}{lcc}
\hline Total Length & $\mathbf{3 8 6 . 2 4}$ & TL\% \\
\hline SL & 352.54 & 91.2 \\
Ld & 218.87 & 56.6 \\
La & 168.56 & 43.6 \\
Lp & 54.56 & 14.1 \\
Lv & 51.37 & 13.3 \\
Lpd & 109.06 & 28.2 \\
Lpa & 170.15 & 44 \\
Lpv & 86.48 & 22.3 \\
Lpp & 101.32 & 26.2 \\
T & 66.18 & 17.1 \\
Tpc & 16.87 & 4.3 \\
Lc & 52.28 & 13.5 \\
Head length & 104.48 & 27 \\
\hline & & HL\% \\
\hline O & 17.41 & 16.6 \\
O (cornea) & 7.68 & 7.3 \\
Po & 33.46 & 32 \\
Olo & 55.48 & 53.1 \\
\hline
\end{tabular}

TL: Total Length, SL: Standard Length, W: Total weight, G: Gender, GW: Gonad weight, HL: Head length, Ld: Dorsal fin length, La: Anal fin length, Lp: Pectoral fin length, Lv: Ventral fin length, Lpd: Predorsal distance, Lpa: Preanal distance, Lpv: Preventral distance, Lpp: Prepectoral distance, T: Max body height, Tpc: Min body height, O: Eye diameter, O (cornea): Cornea diameter, Po: Preocular distance, Olo: Postocular distance

This is the first report of European hake abnormalities in wild fish populations from the Marmara Sea. Fish anomalies have been ascribed to multiple factors like currents (Hilger, 1992; Divanach et al., 1997; Cerezo et al., 2005), temperature variations, $\mathrm{pH}$, salinity fluctuation, and low dissolved oxygen (Milton, 1971; Turner \& Farley, 1971; Gluth \& Hanke, 1983; Boglione et al., 2013), high $\mathrm{CO}^{2}$ concentration in water (Martens et al., 2006), pollutants like chlorinated hydrocarbons, organophosphates, pesticides, and heavy metals (Kessabi et al., 2009; Lin Sun et al., 2009)

There are few papers in the literature about the causes of different deformities in wild fish anomalies (Divananch et al., 1996; Aritaki \& Seikai, 2004; Jonsson \& Jonssoln, 2006; Sanchez et al., 2011). There are some fish anomaly cases in different regions reported as albinism (Baruah, 1968; Jawad \& ibrahim, 2017), melanism (Atz et al., 1963; Berland, 1967; Marcoux, 1966), hermaphroditism (Bullough, 1940; Arme, 1965; Ciechomski \& Christiansen, 1968; Millikan \& Pattie, 1970), deformations in the vertebrae (Cavaliere, 1965; Hoff, 1970; Boglione et al., 2006; Jawad \& Akyol, 2018), deformations of the fins (Hase, 1935; Bennet, 1964; Easwaran, 1968), and malpigmentation (Cerim et al., 2016).

Abnormalities, especially in the Mediterranean fish mariculture, are an important object with many factors, and are generally due to gaps in knowledge about their development (Divanach et al., 1996). Generally, the abnormalities arise as various gross skeletal 
abnormalities for sea bass fish species and may cause dysfunction in calcium metabolism (Valentine, 1975).

A guide has been prepared in order to investigate the anomalies of fishes that are exposed to environmental pollutants or the other effects reported by Smith et al. (2002). In the guide, the anomalies, which are observed in the fish eyes, were noted as opaque or cloudy eye, exophthalmia, missing eye, third eye, hemorrhagic eye, emboli, or gas bubbles in the eye. The congenital absence of the eye has previously been noted in the species Silurus glanis (Necrasov \& Adascalitei, 1970) and Merluccius merluccius (Brian, 1952).

The skeletal anomalies and meristic counts of the three mullet species (Chelon ramada, Chelon labrosus, and Mugil cephalus) have been reported from the Adriatic Sea. However, no anomaly has been found for the Chelon auratus species in the same region. It has been reported that the three mullet species mentioned above are more sensitive to environmental conditions and that there may be differences in sensitivity to the effects of pollutants between species belonging to the same family. (Boglione et al., 2006). A similar situation has been observed among Gobiidae species (Da Cunha and Antunes, 1999). Three anomaly cases have previously been noted for the Merlucciidae family. The hermaphroditism anomalies have been observed for Merluccius hubbsi species in the Buenos Aires coasts in South America (Ciechomski \& Christiansen, 1968) and Merluccius productus species off the coast of Washington in the Pacific Ocean (Millikan \& Pattie 1970) and one eye anomaly has been observed in Merluccius merluccius on the coast of Italy (Brian, 1952) and pug head deformity in the Aegean Sea (Jawad et al., 2018). The authors state that the anomalies in wild fish may be caused by pollution (Bengtsson, 1979; Bengtsson et al, 1985; Carls et al., 1990; Kingsford and Gray, 1996; Haaparanta et al., 1997; Kirchhoff et al., 1999).

Researchers have reported egg malformations in polluted waters of the North Sea (Cameron and Westernhagen, 1997), Baltic Sea (Westernhagen et al., 1988), Australian Coastal Waters (Klumpp \& Westernhagen, 1995), Chilean Waters (Llanos-Rivera et al., 2013), Western Coasts of the Atlantic (Longwell et al., 1992) and the Marmara Sea (Mavruk et al. 2015).

As a result, water inputs such as discharge points in the Sea of Marmara, litter transportation via basins, and high levels of nutrients and organic matter cause eutrophication. Eventually, there is a lack of oxygen in the region, especially in the summer and autumn periods. In addition, plankton and jellyfish blooms, redtide and mucilage events can be encountered throughout the year (Okyar et al., 2015; TÜBITAK MAM, 2017). Mucilage, which was first observed in 2007 and then every year to date, is composed by secreting organic compounds due to the high nitrogen and phosphate input in the Marmara Sea. (Aktan ve diğ., 2008a; Tüfekçi ve diğ., 2010; Balkis-Özdelice ve diğ., 2021). Izmit Bay has smaller industry regions such as Darica, Golcuk, Hereke, Ipras, and Karamursel. Izmit Bay comprises one of the most heavily industrialized regions of northwestern Turkey, with large petrochemical and chemical plants in its surrounding centers. There are also heavy steel industries, textile and related industries, leather tanning and processing plants, and automotive indus- tries in nearby Izmit. Also, the water circulation in the Gulf of Izmit is low, and the living organisms in this region, which are under the influence of pollution due to intense industry, are adversely affected.

\section{CONCLUSION}

In the present study, the anomaly of the absence of the right eye of the European hake specimen obtained from the Marmara Sea was observed and this anomaly is thought to most likely have been caused by pollution. It may also have been caused by a fishing activity such as angling, in which the hook of a handline used in the region could have hooked the eye of the fish in its early stages of life, or it also may have been caused by fish competition in the early stages of the fish's life, or by genetic factors. It is suggested that pollution may have caused the absence of the right eye of the fish because there was no visible injury on the right side of the specimen, and also because of another anomaly reported in the Marmara Sea: the presence of individuals with abnormal development (conjoined twins) belonging to Trachurus mediterraneus (Mavruk et al., 2015). Changes in the ecosystem of the Marmara Sea as a result of anthropogenic effects may cause anomalies in wild fish species. Further studies are needed in order to understand fish anomalies which are caused by environmental pollutants.

Conflict of interests: The authors declare that they have no conflict of interest.

Ethics committee approval: This study does not need any ethical approval.

Financial disclosure: No financial disclosure.

Acknowledgement: The authors would like to thank Enis ISLAMOGLU and Ali SARI, the fisherman, for fishing and supplying the sample.

\section{REFERENCES}

Aktan, Y., Dede A., Çiftçi P.S. 2008. Mucilage event associated with diatoms and dinoflagellates in Sea of Marmara, Turkey. An IOC Newsletter on toxic algae and algal blooms, The Intergovernmental Oceanographic Commission of UNESCO, 36, 1-3.

Aritaki, M. and Seikai, T., 2004. Temperature effects on early development and occurrence of metamorphosis-related morphological abnormalities in hatchery-reared brown sole Pseudopleuronectes herzensteini. Aquaculture 240:517-530. [CrossRef]

Arme, C. 1965. A hermaphrodite specimen of roach, Rutilus rutilus (L.). Proc. Leeds phil. lit. SOC. 9(11):277-281.

Atz, J. W., Kallman, K. D., and Nigrelli, R. F. 1963. Position effect as a factor in the production of melanosis and melanoma in the fish Xiphophorus. Proc. int. Congr. Zool. 16(2) :206.

Balkis-Ozdelice, N., Durmuş, T., Balci, M. 2021. A Preliminary Study on the Intense Pelagic and Benthic Mucilage Phenomenon Observed in the Sea of Marmara. International Journal of Environment and Geoinformatics (IJEGEO), 8(4): 414-422. [CrossRef]

Baruah, M. C. 1968. A case of albinism in Heteroplzeustes fossilis (Bloch) J. Bombay nat. Hist. SOC. $65: 495-496$.

Bengtsson, B.E., 1979. Biological variables, especially skeletal deformities in fish, for monitoring marine pollution. Philos. Trans. R. Soc. Lond. B 286, 457-464. [CrossRef] 
Bengtsson, B.E., Bengtsson, A., Himberg, M., 1985. Fish deformities and pollution in some Swedish waters. Ambio 14, 32-35.

Bennet, P. S. 1964. On an abnormal ray from Vizhingam (Rhynchobatus djiddensis). J. Mar. biol. Ass. India 6(2):316-317.

Berland, B. 1967. A melanistic herring. Fauna, Oslo 20(4):273-274.

Beşiktepe, Ş., Sur, H.i.., Özsoy, E., Latif, M.A., Oğuz, T. and Ünlüata, Ü., 1994, The circulation and hydrography of the Marmara Sea, Prog. Oceanogr, 34:285-334 pp. [CrossRef]

Boglione, C., Marino, G., Bertolini, B., Rossi, A., Ferreri, F., Cataudella, S., 1993. Larval and postlarval monitoring in sea bass: morphological approach to evaluate finfish seed quality. In: Barnabe ; G., Kestemont, P. (Eds.), Production, Environment and Quality. Bordeaux Aquaculture 1992. Eur. Aquacult. Soc., Ghent, Belgium, Spec. Pub. no. 18, pp. 189-204.

Boglione, C., Gavalia, P., Koumoundouros, G., Gisbert, E., Moren, M., Fontagenn, S., Witten, P.E. 2013. Skeletal anomalies in reared European fish larvae and juveniles. Part 1: normal and anomalous skeletogenic processes. Rev. Aqua 5:9-S120. [CrossRef]

Boglione, C., Costa, C., Giganti, M., Cecchetti, M., Di Dato, P., Scardi, M., Cataudella, S. 2006. Biological monitoring of wild thicklip grey mullet (Chelon labrosus), golden grey mullet (Liza aurata), thinlip mullet (Liza ramada) and flathead mullet (Mugil cephalus) (Pisces: Mugilidae) from different Adriatic sites: meristic counts and skeletal anomalies. Ecological Indicators 6: 712-732. [CrossRef]

Brian, A. 1952. Caso mostruoso di un pesce privo di un occhio (Merluccius esculentus Risso). Natura, Milano 43:17-23.

Bruno, D.W., Poppe, T.T., 1996. A Colour Atlas of Salmonid Diseases. Accademic Press, London, 194 pp.

Bullough, W. S. 1940. A case of hermaphroditism in the herring (Clupea harengus, Linn.). Proc. Leeds Phil. lit. SOC. 3:638-641.

Carls, M.G., Rice, S.D., 1990. Abnormal development and growth reductions of pollock, Theragra chalcogramma, embryos exposed to water-soluble fractions of oil. Fish. Bull. 88:29-37.

Carpentieri, P., Colloca, F., Cardinale, M., Belluscio, A., Ardizzone, G.D. 2005. Feeding habits of European hake (Merluccius merluccius) in the central Mediterranean Sea. Fish. Bull. 103:411-416.

Cavaliere, A. 1965. Anomalie della colonna vertebrale in Boops salpa L. Boll. Pesca Pisci. Idrobiol., n. s., 20 (1) :52-59.

Cerim, H., Çelik, M., Yapıcı, S. 2016. Occurrence of colour abnormalities and morphological aberration in common sole Solea solea (L., 1758) captured from the Aegean Sea. Cahiers de Biologie Marine 57(1):85-87.

Ciechomski, J. D. de and Christiansen, H. E. 1968. Un caso de hermafroditismo en la merluza Merluccius merluccius hubbsi (Pisces, Merlucciidae). Physis, B. Aires 27(75) :423-428.

Da Cunha, P.L., Antunes, M.M., 1999. Occurrence of vertebral deformities in Gobiidae (Pisces) from the Tagus estuary. Aquat. Ecol. 33, 281-285. [CrossRef]

Daoulas, Ch., Economou, A.N., Bantavas, I., 1991. Osteological abnormalities in laboratory reared sea-bass (Dicentrarchus labrax) fingerlings. Aquaculture 97, 169-180. [CrossRef]

Divanach, P., Boglione, C., Menu, B., Koumoundouros, G., Kentouri, M. and Cataudella, S. 1996. Abnormalities in finfish mariculture: an overview of the problem, causes and solutions. In: Chatain, B., Saroglia, M., Sweetman, J., Lavens, P. (Eds.), Seabass and Seabream Culture: Problems and Prospects. European Aquaculture Society, Oostende, Belgium, pp. 45-66.

Easwaran, C. R. 1968. On an abnormal ray from the Gulf of Kutch. J. Mar. biol. Ass. India, 1967, 9(1):198-200.

Fisher, W., Bauchot, W.M., Schneider, M. 1987. Fiches FAO d'identification pour les besoins de la pêche révision 1. Méditerranée et mer Noire. Zone de pêche 37, vol. 2: Vertèbres, p. 761-1530. FAO, Rome.

Froese, R. and D. Pauly, Editors. 2020. FishBase. World Wide Web electronic publication. www.fishbase.org, (12/2020).

Galeotti, M., Beraldo, P., de Dominis, S., D'Angelo, L., Ballestrazzi, R., Musetti, R., Pizzolito, S., Pinosa, M., 2000. A preliminary histological and ultrastructural study of opercular anomalies in gilthead sea bream larvae (Sparus aurata). Fish Physiology and Biochemistry 22, 151-157. [CrossRef]

Haaparanta, A., Valtonen, E.T., Hoofmann, R.W. 1997. Gill anomalies of perch and roach from four lakes differing in water quality. Journal of Fish Biology 50:575-591. [CrossRef]

Hase, A. 1935. Über ein hypertrophisches Flossenregenerat beim Goldfisch Carassius auratus L. S.B. Ges. naturf. Fr. Berl. 1935:283-289.

Hilomen-Garcia, G.V., 1997. Morphological abnormalities in hatcherybred milkfish (Chanos canoa, Forsskal) fry and juveniles. Aquaculture 152, 155-166. [CrossRef]

Hoff, J. G. 1970. Vertebral anomalies in a humpbacked specimen of Atlantic silverside, Menidia menidia. Chesapeake Sei. 11(1):54-65. [CrossRef]

Jawad L.A., and Ibrahim M., 2017, On some cases of fish anomalies in fishes from the port of Jubail, Saudi Arabia, Arabian Gulf, International Journal of Marine Science, 7(20): 188-199. [CrossRef]

Jawad L.A., and Akyol O. 2018, Vertebral anomalies in Mullus barbatus (Actinopterygiidae: Osteichthyes: Mullidae), collected from Izmir Bay, North-eastern Aegean Sea, Turkey, International Journal of Marine Science, 8(7): 59-65. [CrossRef]

Jawad, L.A, Ibrahim, M. and Waryani, B., 2018, Incidences of caudal fin malformation in fishes from Jubail City, Saudi Arabia, Arabian Gulf. Fisheries \& Aquatic Life, Vol.26 (Issue 1), pp. 65-71. [CrossRef]

Jawad L.A., and Ibrahim M., 2021, Characterization and possible cause of the fish anomalies so far reported in the vicinity of Jubail city, Saudi Arabia, Arabian gulf, L. A. Jawad (ed.), The Arabian Seas: Biodiversity, Environmental changes and conservation measures, [CrossRef]

Jonsson, B. and Jonsson, N., 2006. Cultured Atlantic salmon in nature: a re- view of their ecology and interaction with wild fish. ICES J Mar Sci 63:1162-1181. [CrossRef]

Kingsford, M.J., Gray, C.A., 1996. Influence of pollutants and oceanography on abundance and deformities of wild fish larvae. In: Schmitt, R.J., Osenberg, C.W. (Eds.), Detecting Ecological. [CrossRef] Impacts: Concepts and Application in Coastal Habitats. Academic Press, Santa Barbara, pp. 233-253.

Kirchhoff, S., Se'vigny, J.-M., Couillard, C.M., 1999. Genetic and meristic variations in the mummichog Fundulus heteroclitus, living in polluted and reference estuaries. Mar. Environ. Res. 47, 261-283. [CrossRef]

Kocataş A, Koray T, Kaya M, Kara O.F. 1993. A review of the fishery resources and their environment in the Sea of Marmara. In: Studies and Reviews, General Fisheries Council for the Mediterranean Sea. Rome, Italy: FAO, pp. 87-143

Marcoux, R. G. 1966. Occurrence of a melanistic paddlefish (Polyodon spathula) in Montana. Copeia 1966 (4):876. [CrossRef]

Mavruk, S. Yüksek, A., Kaya, A., Avşar, D. 2015. Conjoined Twinning Incidences in Trachurus mediterraneus (Steindachner, 1868) Eggs in Southern Marmara Sea. Turkish Journal of Fisheries and Aquatic Sciences 15: 601-607.

Millikan, A. E. and Pattie, B. H. 1970. Hermaphroditism in a Pacific hake, Merluccius productus, from Puget Sound, Washington. J. Fish. Res. Bd. Can. 27 :409-410. [CrossRef]

Necrasov, 0., Adascalitei, E. 1970. Sur quelques modifications morphylogiques correlatives a l'absence congenitale d'un oeil chez Silurus glanis L. Rev. Roum. Biol. (Zool.) 13: 179-186.

Okyar, M. et al. 2015. Changes in abundance and community structure of the zooplankton population during the 2008 mucilage event in the northeastern Marmara Sea. Turkish Journal of Zoology, vol.39, 28-38. [CrossRef]

Sanchez, W., Sremski, W., Piccini, B., Palluel, O., Maillot-Marechal, E., Betoulle, S., Jaffal, A., Ait-Aissa, S., Brion, F., Thybaud, E., Hinfray, N. 2011. Adverse effects in wild fish living down- stream from pharmaceutical manufacture discharges. Environ Intern 37:13421348. [CrossRef] 
Sindermann, C.J.1979.Pollution-associated diseases and abnormalities of fish and shellfish: a review. U.S. Fish. Bull. 76: 717- 749

Smith, S.B., Donahue, A.P., Lipkin, R.J., Blazer, V.S., Schmitt, C.J., and Goede, R.W., 2002, Illustrated field guide for assessing external and internal anomalies in fish: U.S. Geological Survey, Information and Technology Report, 2002-0007, 46 p.

TÜBITAK-MAM ve ÇŞB-ÇYGM 2017. Denizlerde Bütünleşik Kirlilik İzleme İşi 2014-2016 Marmara Denizi Özet Raporu. ISBN: 978-605-5294-72-4, Gebze, Kocaeli.
TUIK 2020. Fisheries statistics. Turkish Statistical Institute. Ankara, Turkey. http://www.tuik.gov.tr/PreTablo.do?alt_id=1005

Tüfekçi, V., Balkıs, N., Beken, C.P., Ediger, D., Mantıkçı, M. 2010. Phytoplankton composition and environmental conditions of a mucilage event in the Sea of Marmara. Turkish Journal of Biology, 34, 199-210.

Valentine, D.W. 1975. Skeletal anomalies in marine teleosts. pp.695-718. In: W.E. Ribelin \& G. Migaki (ed.) The Pathology of Fishes, University of Wisconsin Press, Madison. 